\title{
Serial Crowdfunding, Social Capital, and Project Success
}

Vincenzo Butticè

Massimo G. Colombo

Mike Wright

In this paper, we focus attention on serial crowdfunders, that is, entrepreneurs who repeatedly turn to crowdfunding to finance their projects. We argue that serial crowdfunders take advantage of the social contacts with those that backed their previous campaigns. This internal social capital developed within the platform, which is not available to "normal" serial entrepreneurs, makes serial crowdfunders' campaigns more successful than those launched by novice crowdfunders. However, this type of social capital is a substitute for the internal social capital built by backing other campaigns, and has a limited lifespan. Econometric results on a sample of 31,389 Kickstarter campaigns confirm our contentions. Implications for research, practice, and policy are discussed.

\section{Introduction}

The number of entrepreneurs who repeatedly turn to crowdfunding to finance their projects has grown rapidly in recent years. In Kickstarter, the world's largest rewardbased crowdfunding platform, serial crowdfunders, that is, entrepreneurs who repeatedly launch crowdfunding campaigns, received \$511 million to March 2015-nearly one third of all the money pledged on the platform (Gallager \& Salfen, 2015). Despite the relevance of the phenomenon, scholarly investigation in this area has been limited (Butticè, Franzoni, Rossi-Lamastra, \& Rovelli, in press; Kuppuswamy \& Bayus, 2015). Whether serial crowdfunders are more successful than their novice peers and, if so, which mechanisms drive their success have so far remained unexplored.

This limited attention may originate from the presumption that serial crowdfunders are ultimately the same as serial entrepreneurs, and thus that the large body of knowledge on the factors driving the success of serial entrepreneurs (Ucbasaran, Westhead, \& Wright, 2009) can be applied to serial crowdfunders. We do not share this view. Rather, we argue theoretically and show empirically that factors driving the performance of serial crowdfunders differ from those highlighted by the serial entrepreneurship literature. For this purpose, we follow the established premise in the crowdfunding literature that there

Please send correspondence to: Vincenzo Butticè, tel.: +39 022399 2738; e-mail: vincenzo.buttice@ polimi.it, to Massimo G. Colombo at massimo.colombo@polimi.it, and to Mike Wright at mike.wright@ imperial.ac.uk. 
is a close association between the social capital of entrepreneurs and the success of their campaigns (Agrawal, Catalini, \& Goldfarb, 2011; Colombo, Franzoni, \& RossiLamastra, 2015; Mollick, 2013). We argue that crowdfunding offers entrepreneurs an effective setting to develop "internal" social capital comprising the digital social links with other individuals active on the same platform. Specifically, we posit that crowdfunding gathers a crowd of individuals who share the same values (e.g., being supportive toward other crowdfunding users) and allows entrepreneurs to carve out from this crowd a community ready to support them during subsequent crowdfunding campaigns. This community arises from the intense exchange of information, comments, and advice that occur between the entrepreneur and his/her backers during the campaign and once it reaches the target capital. During their subsequent campaigns, entrepreneurs can rely on this community to ensure campaign success, and, accordingly, serial crowdfunders have an advantage over their novice counterparts. While social capital is also an important resource for "traditional" serial entrepreneurs (Gedajlovic, Honig, Moore, Payne, \& Wright, 2013), they do not have the material opportunity to build a similar community with their existing customers or investors.

Moreover, we argue that as well as this advantage, the community developed by a serial crowdfunder also has its drawbacks. First, this community is made redundant by other forms of social capital developed within the platform; in other words, different forms of internal social capital substitute for each other. So, if project proponents already possess a sufficient amount of social capital within a crowdfunding platform developed by backing other campaigns (Colombo et al., 2015), the additional effect of the social capital originating from their previous successful campaigns is weak. Second, this type of social capital is formed by a greater number of weak ties (Granovetter, 1973), and since it exists within the particular setting of crowdfunding which offers backers many alternatives, it needs to be maintained by launching new campaigns, otherwise it becomes obsolete over time.

We test the above arguments using the population of 31,389 campaigns launched on Kickstarter between 1st January and 12th September 2014. Our results show that the likelihood of running a successful campaign increases with the number of previous successful campaigns run by the same entrepreneur and, more interestingly, this positive effect is fully mediated by the social capital built by launching previous successful campaigns. We also provide evidence that this type of internal social capital has a rather short lifecycle. Its influence on the likelihood of funding vanishes if the time elapsed since the previous campaign exceeds 1.5 years. Moreover, the effect of the internal social capital built by serial crowdfunders from previously successful campaigns is considerably weaker with a greater volume of internal social capital developed from backing other campaigns. Last, we find none of these effects for the backers of unsuccessful crowdfunding campaigns.

This paper makes two main contributions to the literature. First, we contribute to the crowdfunding literature by bringing serial crowdfunders to the fore and showing that they are more successful than their novice peers. The development of a community ready to support the subsequent campaigns of serial crowdfunders is the main explanation of their superior success rate. Second, we contribute to the literature highlighting the role of social capital in enabling entrepreneurs to raise finance for subsequent ventures. This literature shows that entrepreneurs rely on personal contacts to access early-stage finance such as bank loans (Uzzi, 1999), venture capital (VC) funds (Zhang, 2011) and business angels' capital (Brush, Carter, Greene, Hart, \& Gatewood, 2002). Building on this tradition, previous crowdfunding studies have emphasized the paramount importance of the social capital of project proponents (Agrawal et al., 2011; Colombo et al., 2015; Mollick, 2013), 
and we extend this literature by highlighting an alternative method through which entrepreneurs can build social capital within a crowdfunding platform by serially launching new campaigns. We also show that this type of internal social capital has a limited lifecycle, and provide evidence that the different types of internal social capital built within a crowdfunding community substitute for each other. In so doing, we contribute to the general literature on social capital in entrepreneurship by highlighting neglected aspects, particularly regarding its context-specific antecedents, substitutability and longevity (Gedajlovic et al., 2013).

\section{Theoretical Background and Hypotheses}

\section{Serial Entrepreneurship and Firm Performance}

Since MacMillan (1986) highlighted the centrality of serial entrepreneurs in understanding the nature of entrepreneurship, researchers have shown that serial entrepreneurs outperform novice ("one-time") entrepreneurs both in the process of opportunities identification and in exploiting such opportunities (Ucbasaran et al., 2009; Westhead, Ucbasaran, \& Wright, 2005), which leads to better performance in several ways. A survey of private businesses in Scotland showed that firms owned by serial entrepreneurs have significantly larger revenues than those owned by novice entrepreneurs (Westhead, Ucbasaran, \& Wright, 2003), while Gompers, Kovner, Lerner, and Scharfstein (2010) obtain a similar result in a study of U.S. VC-backed firms. Serial entrepreneurs are perceived by external parties to possess greater skills and, thus, are able to collect more valuable resources from suppliers and customers. In turn, these resources help serial entrepreneurs outperform their novice competitors in terms of revenues and profitability (Parker, 2013).

Scholars typically explain serial entrepreneurs' higher performance by grounding in theories of entrepreneurial learning-by-doing (Cope, 2005). In this vein, serial entrepreneurs outperform novice counterparts especially when they have previously successful entrepreneurial experiences (Gompers et al., 2010). Moreover, Hsu (2007) and Wright, Robbie, and Ennew (1997) show that serial entrepreneurs can negotiate better terms with VC investors, having learnt from prior experiences. Similarly, Lafontaine and Shaw (2014) argue that running several ventures over time leads serial entrepreneurs to develop general managerial skills, which increase the longevity of the serial entrepreneur's next firm-interestingly, this effect remains when controlling for individual fixed effects.

Another strand of literature, rooted in the resource-based view (Barney, 1991), highlights that serial entrepreneurs acquire a set of rare resources over time that lead to competitive advantage and improved performance in subsequent ventures (Baert, Meuleman, DeBruyne, \& Wright, in press). Similarly, Shaw and Carter (2007) show serial entrepreneurs re-use resources from previous ventures, with social capital playing an especially important role (Eggers \& Song, 2014).

Entrepreneurs develop social connections when running a new venture (Gedajlovic et al., 2013) and serial entrepreneurs make use of this social capital when they start subsequent firms (Wiklund \& Shepherd, 2008). Hsu (2007) finds that serial entrepreneurs are more likely to receive VC funding than novice entrepreneurs as they can leverage social ties established in the capital market during their previous entrepreneurial experiences, yet this funding may be from VCs other than the ones funding their original venture (Wright et al., 1997). In accordance with this view, serial entrepreneurs, being more socially connected than novice entrepreneurs, not only gain access to VC more quickly but raise more VC funds (Zhang, 2011). Similar evidence has been found for bank loans 
(Uzzi, 1999) and capital provided by business angels (Brush et al., 2002). In the following sections, we develop hypotheses on the relationships between social capital and serial crowdfunders campaign success.

\section{Serial Entrepreneurship in Crowdfunding: What Drives the Success of Serial Crowdfunders?}

Serial entrepreneurship has so far received limited attention in the crowdfunding literature. This is an important omission since serial crowdfunders are a special type of serial entrepreneurs. In particular, there are sound theoretical reasons to expect that the factors making serial crowdfunders more successful than their novice peers differ quite substantially from the ones highlighted by the serial entrepreneurship literature. These differences mainly relate to the internal social capital consisting of the links serial crowdfunders have developed with backers of their earlier successful crowdfunding campaigns.

In analyzing factors driving crowdfunding campaign success, the literature has pointed to the crucial importance of social capital to increase the likelihood of success. In crowdfunding, success breeds success, so reaching a large number of backers in the early days of a campaign dramatically increases the odds of the campaign reaching the target capital (Wash, 2013). Thus, entrepreneurs able to mobilize the support of their social contacts in the early days of the campaign enjoy an obvious advantage (Colombo et al., 2015; Vismara, 2016). In accordance with this view, previous studies stressed the effects of family, friends (Agrawal et al., 2011), and personal acquaintances (Mollick, 2013), showing that both direct and online contacts are relevant for raising money.

Colombo et al. (2015) consider a different form of social capital developed within the crowdfunding platform, that is, "internal" social capital, arguing that crowdfunding platforms represent a privileged forum for the creation of social contacts. By backing others' campaigns, entrepreneurs are able to join a virtual community of individuals who perceive a sense of mutual identification (Nahapiet \& Ghoshal, 1998) and share a set of supportive behaviors toward their peers. Individuals in this community are motivated to provide funding, feedback, and visibility on projects of other members. Due to a feeling of mutual obligation (Coleman, 1988), having backed others' campaigns triggers reciprocity and leads community members to provide funding and/or visibility to the project among their circles.

We posit that launching successful campaigns is an alternative way to develop internal social capital. Specifically, we argue that through successful crowdfunding campaigns, entrepreneurs can carve out a virtual community of followers from the crowd of backers, which helps them during subsequent campaigns.

Virtual communities emerge when individuals pursue a common goal (Jones, Ravid, \& Rafaeli, 2004; von Krogh, Spaeth, \& Lakhani, 2003), feel they have a positive and measurable impact on the final output (Blanchard \& Markus, 2004), develop emotional connection to the project (Greer, 2000; Preece, 1999), and have frequent interactions with the core members of the project (Mockus, Fielding, \& Herbsleb, 2002).

Successful crowdfunding campaigns allow entrepreneurs to aggregate a group of backers who share these features. Through these campaigns, entrepreneurs gather individuals with a common purpose, that is, to ensure crowdfunding campaign success and favor the production and delivery of high quality products, and whose actions have a positive and measurable impact on the project, that is, the amount of funding provided. Typically, these individuals develop emotional connections with the entrepreneurs (Gerber, Hui, \& Kuo, 2012; Richter, 2015) and often interact with them. Specifically, once a campaign is 
launched, many interactions between entrepreneurs and backers occur, as the latter show their appreciation for the project, and start inquiring about product features. If the campaign does not obtain the funding target, these interactions decrease and ultimately stop. In contrast, if the project collects sufficient financial capital, interactions continue further and backers typically raise questions about the production process, product delivery, and customization (Belleflamme, Lambert, \& Schwienbacher, 2014).

Being a member of the serial crowdfunder virtual community influences backers' behavior twofold. On the one hand, it drives backers to actively support new campaigns launched by the entrepreneur, due to the emotional connection they developed with the community (Wasko \& Faraj, 2000). As backers have an incentive to support the new projects posted by the entrepreneur to keep the community alive (Wellman \& Gulia, 1999), they participate in the new campaign either directly, through funding, or indirectly, by advertising it in their circles. In addition, the community generates peer pressures (Wasko \& Faraj, 2005) on backers who do not intend to participate in the campaign. If so, these backers may support the campaign to avoid jeopardizing their reputation and to prevent retaliation (Faraj \& Johnson, 2011). On the other hand, being a member of the serial crowdfunder community creates emotional attachment that leads backers to seek updated information about the project and the entrepreneur's actions. To this end, the members of the community start following the entrepreneur's social network pages, making backers immediately aware of the new funding campaign launched by the entrepreneur. This in turn increases the likelihood that they back the new campaign in a timely manner. If this occurs, the new campaign has higher chances of success because it triggers observational learning among the other members of the crowdfunding platform (Colombo et al., 2015; Vismara, 2016) — in other words, a virtuous circle is created and enhanced with each successful campaign.

This community-building dynamic is specific to crowdfunding. In traditional settings, although serial entrepreneurs develop relationships with trading and financial partners, the possibility to carve out a community from a crowd of potential backers willing to help is usually precluded. In this case, entrepreneurs' social contacts do not typically feel they are members of a community and do not pursue the same goal in unison (Bengtsson, 2013). Accordingly, community motivations to support a serial entrepreneur's new venture do not apply, which also means that the incentive to keep the community alive and peer pressure to proactively participate in the new venture is limited. In addition, trading and financial partners typically have limited, if any, emotional connection with the entrepreneur. Last, observational learning dynamics play a less important role in determining the success of serial entrepreneurs than in crowdfunding. In sum, serial entrepreneurs in a traditional context can only enjoy limited, if any, network advantages and typically rely on existing acquaintances.

Following these arguments, we predict that serial crowdfunders experience a higher rate of success the greater the number of previous successful campaigns they launched, mainly deriving from the internal social capital serial crowdfunders develop across campaigns. Hence:

Hypothesis 1: The larger the number of previous successful campaigns launched by the project proponent, the greater the likelihood of success of a crowdfunding campaign. This effect is mediated by social capital from previous successful campaigns launched by the project proponent.

We do not expect a similar effect when previous campaigns launched by a serial crowdfunder were unsuccessful. If the campaign does not attain the target capital, the 
serial crowdfunder cannot cash-in the funding and typically halts the project. In this scenario, backers do not have any serious motive to follow a serial crowdfunder's social network pages and, as the social interactions between backers and serial crowdfunders are limited, backers are quite unlikely to participate in the future campaign, or to advertise it among their social connections. Thus, we expect only social capital acquired from previous successful campaigns to be a powerful trigger for serial crowdfunder success.

\section{The Interaction Between Social Capital From Previous Successful Campaigns and Social Capital From Backing Others' Activities}

Compared to traditional settings, where entrepreneurs usually receive funding and guidance in a unidirectional way (Hsu, 2007), in crowdfunding individuals can be funding-seekers and funders of other projects simultaneously, and thus occupy a position on both sides of the market. Occasionally, serial entrepreneurs in traditional settings also operate as business angels (Brettel, 2003); however, they are less likely to be seeking funding and investing at the same time. In contrast to crowdfunding platforms, VCs likely take a negative view of entrepreneurs who approach them for funding while at the same time using some of their own funds to invest elsewhere as this likely signals a lack of commitment and focus (Trester, 1998).

This characteristic of crowdfunding allows serial crowdfunders to develop social capital within the platform in multiple ways, but raises additional challenges about managing this resource. Managing the internal social capital obtained by backing others' projects and the social capital attracted from previous crowdfunding campaigns requires the performance of different actions. On the one hand, serial crowdfunders have to post updates about their project, answer backers' questions, and agree upon possible product customizations when they interact with backers of their previous successful campaigns. On the other, they are required to provide feedback, and advertise others' products to maintain relationships established by backing others' campaigns (Colombo et al., 2015).

These activities are inherently different and may compel serial crowdfunders to split their efforts. If they devote increasing attention to maintaining contacts with their previous backers, they risk overlooking the contacts they have created on the crowdfunding platform while backing others' campaigns. Similarly, if crowdfunders nurture internal social capital developed by backing others' campaigns, they are unlikely to have enough time and attention to nurture the community of backers in their own projects. This argument finds support in studies highlighting that typical entrepreneurs imperfectly manage social capital (Maurer \& Ebers, 2006). They often spend too much time with selected contacts, without correctly assessing the opportunity cost of these links (Steier \& Greenwood, 2000), and consequently, have too little time to manage other potentially fruitful contacts.

Neglecting social contacts risks weakening the relationship built on the platform (Burt, 2002), leading to loss of efficacy of social capital (Adler \& Kwon, 2002). Accordingly, when serial crowdfunders have already developed social capital by backing others' projects, the positive effect of social capital developed through previous successful campaigns is weakened (i.e., these two forms of social capital substitute for each other). Thus:

Hypothesis 2: The greater the social capital developed by the project proponent through backing others' projects, the weaker the association between the likelihood of success of a crowdfunding campaign and social capital from previous successful campaigns launched by the project proponent. 


\section{Persistence of Social Capital From Previous Successful Campaigns Over Time}

Resources possessed by firms and individuals are well known to depreciate over time (e.g., Bessen, 2008; Mincer \& Ofek, 1982). This depreciation is higher with a greater timelag since the resource was created or maintained (e.g., Albrecht, Edin, Sundström, \& Vroman, 1999; Bessen). Social capital is no exception. Ties dissolve when relationships no longer provide critical resources and/or information (Gulati \& Gargiulo, 1999; Ingram \& Torfason, 2010). If so, the parties involved start seeking alternatives, and, once found they let existing ties decay (Baker, Faulkner, \& Fisher, 1998; Broschak, 2004). This process is fostered when the environment offers a large set of alternative partners (Dahlander $\&$ McFarland, 2013) and when existing ties are based on sporadic interactions (Seabright, Levinthal, \& Fichman, 1992). In this case, ties are subject to the golden rule of "out of sight out of mind." If no longer activated, they weaken and ultimately decay (Prashantham \& Dhanaraj, 2010).

We argue that this process is particularly strong in crowdfunding. Unlike traditional settings, where relationships are typically based on repeated interactions (Hsu, 2007) which facilitate the emergence of shared social norms (Nahaphiet \& Ghosal, 1998), trust (Moran, 2005), and the emergence of strong ties (Granovetter, 1973), crowdfunding is mainly based on online contacts, which are typically scattered and loose (Ellison, Steinfield, \& Lampe, 2007). Accordingly, the social capital developed through these interactions is formed by comparatively weaker ties (Donath \& Boyd, 2004) that eventually become inactive. As time elapses after the end of a campaign, the interactions between serial crowdfunders and backers becomes progressively less intense. Project updates are less frequent, tending to disappear when the product is introduced into the market, while backers lose interest in serial crowdfunders' social network pages (Kwak, Moon, \& Lee, 2012), even if serial crowdfunders continue to attempt social interaction with them.

Moreover, in crowdfunding new campaigns are launched daily by the various platform members, so this funding method favors the search for alternative projects and facilitates the mobility of backers from one entrepreneur to another. Due to the transparency of information on the platform, over time backers move on to pitches by other entrepreneurs and start following them, which exacerbates the loss of interest in previously followed serial crowdfunders' social network pages. If so, backers may ignore subsequent campaigns by serial crowdfunders or even unfollow them. Hence:

Hypothesis 3: The positive association between the likelihood of success of a crowdfunding campaign and social capital from previously successful campaigns launched by the project proponent becomes weaker the longer the time elapsed since the last successful campaign.

\section{Method}

\section{Context of the Study and Sample}

We used data from the U.S.-based platform Kickstarter.com, which is the largest reward-based crowdfunding provider worldwide (Mollick \& Nanda, 2015). Since its inception in April 2009 and up to October 2016, the platform has hosted 322,873 campaigns and has helped crowdfunders around the world raise $\$ 2.67$ billion in pledged capital (see Kickstarter statistics retrieved on October 22, 2016 from https://www.kickstarter. 
com/help/stats). Kickstarter's popularity is partly due to the platform's generalist approach, hosting projects from different industries including art, comics, crafts, dance, design, fashion, film, food, games, journalism, music, photography, publishing, technology, and theater.

Kickstarter has not allowed project proponents to reward backers' contributions with financial returns, either in the form of equity shares or as an interest rate. Instead, Kickstarter has favored the offering of products, services, or gadgets, advising project proponents to offer a range of rewards tied to different pledges to encourage more backers. Some rewards, typically associated with contributions of a few dollars, are merely symbolic, while others involve the prepurchase of the product or service and are associated with higher pledges, with the platform allowing proponents to price rewards between $\$ 1$ and $\$ 10,000$. However, project proponents normally do not charge rewards above $\$ 1,000$.

Kickstarter has always employed an all or nothing business model, meaning that crowdfunders cash in the money only if the capital pledged at the closure of the campaign is greater than the funding goal (called on the platform "target capital"). However, campaigns are kept active until their expected deadline even if they have already met the funding goal, so campaigns can raise more than $100 \%$ of the amount requested.

Using data from an all or nothing platform is particularly convenient for our objective because it allows us to build a clear-cut measure of crowdfunding success. We follow previous studies in defining "successful" a campaign that meets the target capital within the campaign duration. Focusing on Kickstarter offers other advantages; first, Kickstarter provides numerous and easily accessible data for testing our hypotheses; second, this setting offers an ideal test-bed for empirical work, indeed, it allows us to control for the information backers could use when they took the decision; and Kickstarter data have been used in several prior studies (e.g., Colombo et al., 2015; Mollick \& Nanda, 2015; Pitschner \& Pitschner-Finn, 2014).

We studied all campaigns launched by individuals on Kickstarter from 1 January 2014 to 12 September 2014, excluding campaigns launched by both established firms and groups of people. The final sample includes 31,389 campaigns in different categories. For each project proponent, we keep track of any campaign they had launched on Kickstarter since its inception to the launch day of the focal campaign. To test the hypotheses on social capital depreciation, we focused on a subsample of campaigns launched by serial crowdfunders during the same time period, which amounted to 3,937 campaigns.

\section{Variables}

We collected information on crowdfunders' previous activities using the platform; first, counting the number of funding campaigns the project proponent had posted since the opening of Kickstarter, by keeping separate track of previous successful campaigns (number of previous successful campaigns) and unsuccessful funding attempts (number of previous unsuccessful campaigns). Second, we computed the cumulative number of comments that a serial crowdfunder had received on previous successful campaigns (social capital from successful campaigns). This measure is a proxy of social capital developed through previous campaigns. Existing literature shows that social capital is a resource associated with relationships (Coleman, 1988) and interactions (Chua, Lim, Soh, \& Sia, 2012; Wasko \& Faraj, 2005), which in online settings typically take the form of emails or comments posted on personal social network pages (Antoci, Sabatini, \& Sodini, 2012). These comments allow us to better proxy a complex construct such as social capital. Here, our assumption is that comments are mainly positive in nature and negative 
comments about crowdfunding campaigns are sporadic. ${ }^{1}$ Finally, we kept track of the time (expressed in days) elapsed since previous campaign (time).

We include several control variables. We used information about Facebook friends at the point of campaign launch (external social capital) as a proxy of external social capital (Mollick, 2013). With respect to other project proponents' social networks (e.g., LinkedIn), we prefer this measure for three reasons; first, this information is reported in the project description and is therefore publicly available to backers when they decide whether to support the crowdfunding campaign or not. Second, the number of Facebook friends, unlike LinkedIn connections, also includes relationships based on kinship and friendship, and these relationships are especially important in affecting the funding dynamics in early stages of campaigns (Agrawal et al., 2011). Finally, the number of Facebook friends has been used in prior studies (e.g., Mollick, 2013), thus making our results easily comparable with the extant literature. Like these studies, we also considered whether the project proponent had no Facebook account when launching the campaign (d_nofacebook). In addition, taking inspiration from extant literature (Colombo et al., 2015), we coded a second measure of social capital developed within the crowdfunding platform. Analogous to social capital from successful campaigns, this is the number of comments that the proponent had posted on backed projects at the point of focal project launch (social capital from backing activity). This represents the degree to which project proponents had been active within the platform and is a proxy of their social connections with peers.

Another set of information relates to the funding campaign. We collected the number of visuals (videos plus images) contained within the project description (ln_visuals) and the number of links to external websites containing further information about the project (more information). Literature has stressed that these reduce information asymmetries about the quality of the project, thus making the funding more likely (Mollick, 2013). We also considered the duration of the campaign (duration), and its target capital expressed in dollars (In_target) — where the project made use of currencies different from dollars, we used a monthly average exchange rate to make all figures comparable. We also coded whether the project was located in the United States (d_US), and added a dummy variable $d$ staff pick intended to control for the campaign quality. This variable assumes value 1 if the campaign was selected by Kickstarter as "staff picks," 2 which, according to the Kickstarter blog, are projects which excelled in their campaign design by including all the information relevant for backers. When a project is selected as a staff pick, the proponent is allowed to include a staff picks badge in the campaign header and the project is shortlisted in a dedicated section of recommended projects. Descriptive evidence suggests that these projects enjoy greater visibility on both Kickstarter and in the specialized press. Category dummy variables were created following the Kickstarter taxonomy and were included in the set of controls.

A final set of information relates to the rewards offered in the campaign. Following extant work (Butticè \& Colombo, in press), we collected information on three specific categories of rewards by means of three dummy variables. We keep track of rewards that offer

1. To assess the validity of this assumption, we created a representative subsample stratified over three dimensions: project size, project category, and serial versus novice crowdfunders. From these 384 campaigns, we downloaded all the comments received and their timing, collecting 5,802 comments. We analyzed the content of such comments with two alternative sentiment analysis tools: LIWC and VADER (Hutto \& Gilbert, 2014). We found that only a small minority of comments were negative, and typically came late in the campaign. Excluding negative comments from computation, the correlation with the variable social capital from successful campaigns is about $97 \%$. Results are consistent with both tools.

2. After recent updates, staff picks are now called "project we love" in the Kickstarter realm. 
customized products, such as an iPhone multipurpose cover with a backer-designed pattern (d_customized), introduce a dummy variable $(d$ ego $)$ to denote projects that offer rewards that trigger backers' intrinsic motivation to participate in a campaign for self-satisfaction (e.g., the inclusion of the backers' name on a public webpage or in the film credits), and we collect information about "community-belonging" rewards. These rewards favor social interaction and may involve the offering of symbolic objects meant to display support for a project ( $d$ _community). To create these variables, we run a content analysis algorithm, based on a search of characterizing terms in the textual description of the rewards. ${ }^{3}$

\section{Descriptive Statistics}

Table 1 reports preliminary descriptive statistics and the correlation matrix of the variables included in our models. Our final sample includes 31,389 campaigns launched by 27,452 distinct crowdfunders. Of these, 3,937 campaigns were launched by 1,030 serial crowdfunders. On average, serial crowdfunders launched 1.76 (standard deviation [SD]: 18.40) successful campaigns and 0.52 (SD: 0.30) unsuccessful campaigns before the launch of the focal campaign. Through these campaigns, they attracted on average 549 backers (SD: 2,716) and 5.21 backers (SD: 30 backers), respectively.

The time elapsed between two campaigns launched by a serial crowdfunder is on average 315 days (SD: 343 days). However, this figure varies significantly depending on the result of serial entrepreneurs' previous campaigns. When these did not meet the target capital, serial crowdfunders returned on average after 155 days (SD: 364 days). In contrast, when their previous campaign had been a success, serial crowdfunders posted a new campaign on average 381 days later (SD: 311 days).

In about one case in three $(31 \%)$, crowdfunding campaigns met the target capital by closure but success is not evenly distributed across categories. Successful campaigns are more frequent among projects related to theater or dance (40\% of success), while they are much less common among both food and journalism projects (17\% of success). On average, crowdfunders seek to raise $\$ 44,216$. However, there is considerable variance across campaigns, and approximately half of the campaigns have a target capital of $\$ 5,000$ or lower. Target capital significantly differs across categories too. Campaigns related to art and craft usually seek a small amount of investment (average target capital: $\$ 10,893$ ), whereas journalism and food campaigns have an average target capital equal to $\$ 71,460$ and $\$ 74,862$, respectively. We kept this in mind when running our estimates. Descriptive statistics show much less variance in campaign duration-on average, a crowdfunding campaign lasts 35 days (SD: 15 days), with frequent durations being 15, 30, and 60 days.

We also computed separate descriptive statistics for the groups of serial and novice crowdfunders, as reported in Table 2. The success rate among serial crowdfunders is significantly higher than novice entrepreneurs; in 1,803 of the 3,937, crowdfunding campaigns launched by serial crowdfunders reached the target capital (45.8\%). This is in line with prior literature on serial entrepreneurs, which highlighted that serial entrepreneurs typically outperform their novice counterparts (Ucbasaran, Wright, \& Westhead, 2003; Westhead et al., 2005). Moreover, campaigns launched by serial crowdfunders are on average 2 days shorter, provide less information through external links, and offer more

3. Thus, in building, for instance, the variable $d_{-}$customized we looked for the presence of words containing the root "custom" or its synonyms. The appropriateness of this methodology has been tested on a sample of 669 projects whose rewards had been human-classified. Computer-based evaluations were in line with the results provided by the human evaluators in 98 cases out of 100 . 


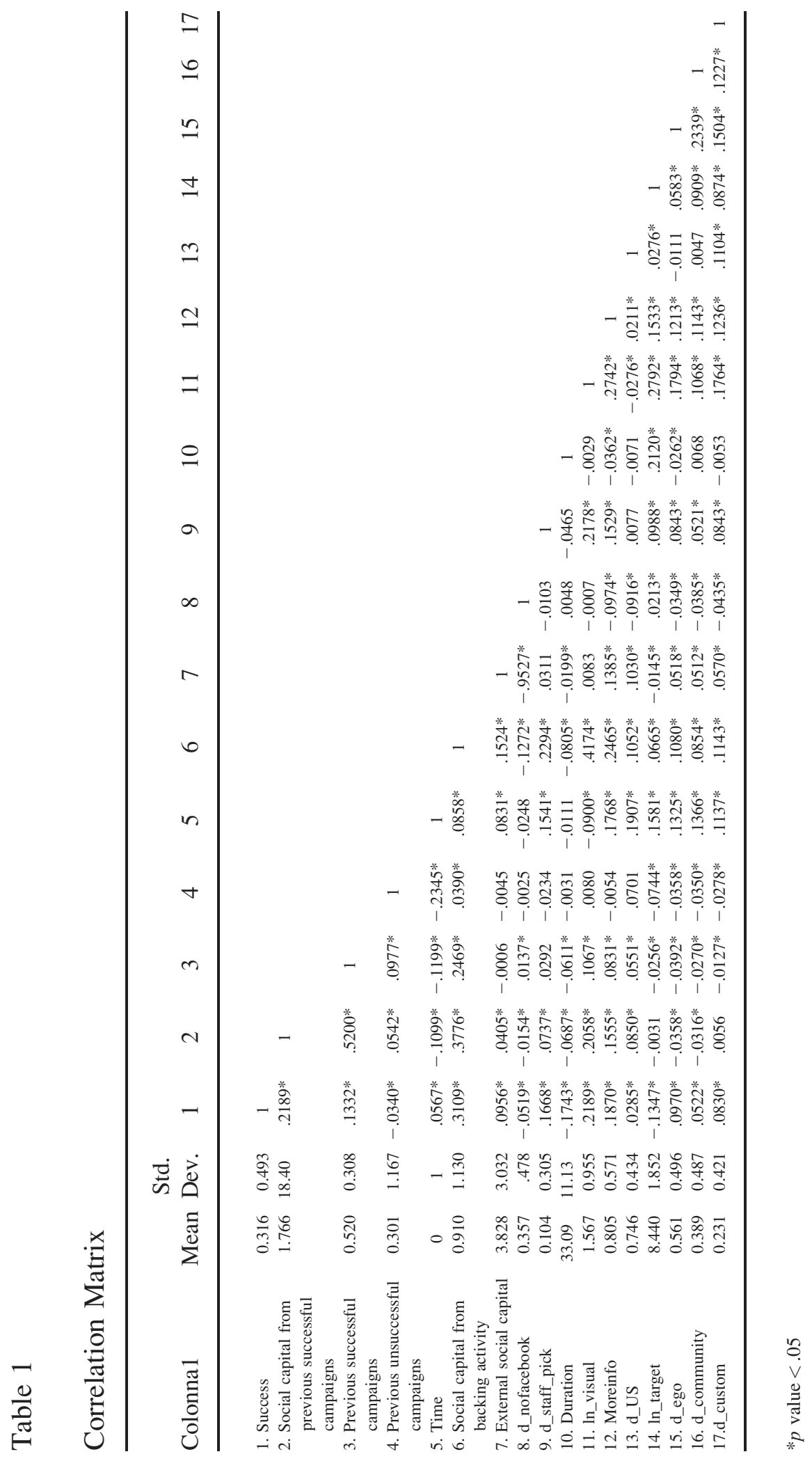


Descriptive Statistics on Serial and Novice Crowdfunders

\begin{tabular}{lccc}
\hline & $\begin{array}{c}\text { Serial } \\
\text { crowdfunders }\end{array}$ & $\begin{array}{c}\text { Novice } \\
\text { crowdfunders }\end{array}$ & $\begin{array}{c}\text { Two } \\
\text { tails } \text { t-test }\end{array}$ \\
\hline Observations & 3,937 & 27,452 & $* *$ \\
Success & .4589 & .2882 & \\
Target capital (\$) & $(.002)$ & $(.006)$ & $* *$ \\
& 38526.61 & 44432.31 & $* *$ \\
Duration (days) & $(7957)$ & $(18514)$ & $* *$ \\
Rewards (count) & 31.78 & $(.155)$ & \\
Additional link (count) & $(.065)$ & 7.772 & \\
& 9.012 & $(.093)$ & \\
& $(.033)$ & $(.011$ & \\
\hline
\end{tabular}

$* * p$ value $<.01$

rewards. No statistically significant differences exist as regards the campaign target capital.

To further investigate how serial crowdfunders adapt campaign design over campaigns, we computed additional statistics, by selecting specific campaign features and calculating the differences between the values that these variables assume over subsequent campaigns with the ones assumed in the first campaign. Serial crowdfunders typically seek a greater amount of money during the second campaign, yet in subsequent campaigns target capital is aligned with that of the first campaign and the difference is not statistically significant (Table 3). Similarly, no statistically significant difference is detected when considering campaign duration, the number of rewards offered, and the number of external links.

Finally, we calculated the ratio of pledged capital to target capital. Consistent with previous work (e.g., Colombo et al., 2015; Wash, 2013), this variable shows a bimodal distribution. The Hartigan dip statistic is significant at $1 \%$, while the modes are around $0 \%$ and $100 \%$ of the target capital. This evidence corroborates the use of a dummy variable (success) to indicate campaigns that successfully met the target capital. The distribution is consistent when separately considering campaigns launched by serial and novice entrepreneurs.

\section{Results}

We model the probability of crowdfunding campaign success using a set of probit estimates. We estimate robust standard errors that account for possible biases and inconsistencies due to heteroscedasticity.

\section{The Impact of Social Capital From Previous Campaigns on the Likelihood of Success of the Crowdfunding Campaign}

Table 4 reports the results of our estimates. First, we consider control variables (see Model I) and all the signs are in line with prior crowdfunding literature (see Butticè et al., 


\section{Descriptive Statistics Over Serial Crowdfunders' Campaigns (Differences Over the First Campaign)}

\begin{tabular}{|c|c|c|c|c|c|}
\hline & $\begin{array}{c}\text { Campaign } \\
1\end{array}$ & $\begin{array}{c}\text { Campaign } \\
2\end{array}$ & $\begin{array}{c}\text { Campaign } \\
\mathbf{3}\end{array}$ & $\begin{array}{c}\text { Campaign } \\
4\end{array}$ & $\begin{array}{c}\text { Campaign } \\
5\end{array}$ \\
\hline Target capital (\$) & 35822.3 & 72757.81 & 37098.47 & 37178.87 & 33942.52 \\
\hline $\begin{array}{l}\text { Difference between the } \mathrm{i} \text { campaign } \\
\text { and the first campaign }\end{array}$ & & $+36935.51^{* *}$ & +1276.17 & +1356.57 & -1879.78 \\
\hline Duration (Days) & 32.84272 & 32.17557 & 31.31870 & 31.77678 & 31.78638 \\
\hline $\begin{array}{l}\text { Difference between the i campaign } \\
\text { and the first campaign }\end{array}$ & & -.66714 & -1.52902 & -1.06593 & -1.05633 \\
\hline Rewards (Count) & 7.11068 & 8.68178 & 8.43568 & 8.53918 & 7.45575 \\
\hline $\begin{array}{l}\text { Difference between the i campaign } \\
\text { and the first campaign }\end{array}$ & & +1.5711 & +1.325 & +1.4285 & +0.34507 \\
\hline Additional link & 0.98345 & 1.02803 & 1.06245 & 1.08224 & 1.11749 \\
\hline $\begin{array}{l}\text { Difference between the i campaign } \\
\text { and the first campaign }\end{array}$ & & +0.04458 & +0.079 & +0.09879 & +0.13404 \\
\hline
\end{tabular}

$* * p$ value $<.01$

in press, for a review). Entrepreneurs' social capital appears a key driver of the success of a crowdfunding campaign. Both social capital from backing activity and external social capital increase the chance of success. With all other continuous variables at their mean value and dummies at median value, a one SD increase of social capital from backing activity results in a $60 \%$ increase in the probability of success (from $26 \%$ to $42 \%$ ), while a one SD increase in external social capital results in a $66 \%$ increase (from $26 \%$ to $43 \%$ ). These values are similar to those highlighted by previous studies (Colombo et al., 2015; Mollick, 2013). In line with prior studies (Mollick), having no Facebook friends is better than having few connections in the social network. Indeed, when the dummy variable $d$ nofacebook assumes value 1 , the likelihood of success increases by $86 \%$ (from $26 \%$ to $4 \overline{8} \%$ ). This value is comparatively higher than the increase in the probability of success occurring for low values of the variable external social capital.

Being included in the "staff picks" entails an increase in the likelihood of success of $50 \%$ (from $26 \%$ to $39 \%$ ). The likelihood of success of the campaign decreases with the duration and the size of the campaign's target capital. The effects of these two variables have non negligible economic magnitude: a one SD increase in the variables leads to a $15 \%$ (from $26 \%$ to $22 \%$ ) and $30 \%$ (from $26 \%$ to $18 \%$ ) decrease in the likelihood of success. The number of images and videos (ln_visual) included in the project description shows a positive and significant coefficient $(p<.001)$ with a magnitude of $38 \%$ (from $26 \%$ to $36 \%$ ). The coefficient of more information, a proxy for the completeness and accuracy of the information provided by the project proponent, is positive and significant $(p<.01)$ with a magnitude of $20 \%$ (from $26 \%$ to $31 \%$ ). We do not find any significant effect of projects' geographical location on the likelihood of success. Compared to the baseline offering only the prepurchase of the product, including the possibility to customize products is associated with an $11 \%$ increase in the likelihood of success. Likewise offering ego-boosting rewards entails an increase in success likelihood of $10 \%$. Conversely, the coefficient of $d$ community is not statistically significant. Thus, there is no 


\begin{tabular}{|c|c|c|c|c|c|c|}
\hline & I & II & III & IV & V & VI \\
\hline $\begin{array}{l}\text { Previous successful } \\
\text { campaigns }\end{array}$ & & $\begin{array}{l}0.1210^{* * *} \\
(0.015)\end{array}$ & $\begin{array}{c}0.0211 \\
(0.030)\end{array}$ & $\begin{array}{l}0.0145 \\
(0.023)\end{array}$ & $\begin{array}{c}0.0235 \\
(0.028)\end{array}$ & $\begin{array}{c}0.0388 \\
(0.031)\end{array}$ \\
\hline $\begin{array}{l}\text { Previous unsuccessful } \\
\text { campaigns }\end{array}$ & & $\begin{array}{l}-0.5444 * * * \\
(0.044)\end{array}$ & $\begin{array}{l}-0.5276^{* * * *} \\
(0.044)\end{array}$ & $\begin{array}{l}-0.5276^{* * * *} \\
(0.053)\end{array}$ & $\begin{array}{l}-0.6094 * * * \\
(0.056)\end{array}$ & $\begin{array}{l}-0.6267^{* * * *} \\
(0.056)\end{array}$ \\
\hline $\begin{array}{l}\text { Social capital from } \\
\text { previous successful } \\
\text { campaigns }\end{array}$ & & & $\begin{array}{l}0.061 * * * \\
(0.007)\end{array}$ & $\begin{array}{l}0.1369 \text { *** } \\
(0.017)\end{array}$ & $\begin{array}{l}0.0752^{* * *} \\
(0.016)\end{array}$ & $\begin{array}{l}0.0814 * * * \\
(0.016)\end{array}$ \\
\hline $\begin{array}{l}\text { Social capital from previous } \\
\text { successful campaigns x } \\
\text { social capital from } \\
\text { backing activity }\end{array}$ & & & & $\begin{array}{l}-0.0261^{* * * *} \\
(0.005)\end{array}$ & & \\
\hline Time & & & & & $\begin{array}{r}0.0125 \\
(0.021)\end{array}$ & $\begin{array}{l}0.0529 * \\
(0.030)\end{array}$ \\
\hline $\begin{array}{l}\text { Time } \mathrm{x} \text { social capital from } \\
\text { previous successful projects }\end{array}$ & & & & & & $\begin{array}{l}-0.0319^{* * * *} \\
(0.007)\end{array}$ \\
\hline $\begin{array}{l}\text { Social capital from } \\
\text { backing activity }\end{array}$ & $\begin{array}{l}0.2644 * * * \\
(0.008)\end{array}$ & $\begin{array}{l}0.2501 * * * \\
(0.010)\end{array}$ & $\begin{array}{l}0.2437 * * * \\
(0.010)\end{array}$ & $\begin{array}{l}0.2546^{* * *} \\
(0.011)\end{array}$ & $\begin{array}{l}0.1307 * * * \\
(0.022)\end{array}$ & $\begin{array}{l}0.1312^{* * *} \\
(0.022)\end{array}$ \\
\hline external social capital & $\begin{array}{l}0.1523^{* * * *} \\
(0.010)\end{array}$ & $\begin{array}{l}0.1477^{* * *} \\
(0.010)\end{array}$ & $\begin{array}{l}0.1466^{* * * *} \\
(0.010)\end{array}$ & $\begin{array}{l}0.1475^{* * * *} \\
(0.010)\end{array}$ & $\begin{array}{l}0.0754^{* * *} \\
(0.025)\end{array}$ & $\begin{array}{l}0.0749 * * * \\
(0.025)\end{array}$ \\
\hline d_nofacebook & $\begin{array}{l}0.9015^{*} \\
(0.062)\end{array}$ & $\begin{array}{l}0.8712 * * \\
(0.062)\end{array}$ & $\begin{array}{l}0.8630^{* *} \\
(0.062)\end{array}$ & $\begin{array}{l}0.8784 * * \\
(0.062)\end{array}$ & $\begin{array}{l}0.4449 * * \\
(0.158)\end{array}$ & $\begin{array}{l}0.4498^{* * *} \\
(0.158)\end{array}$ \\
\hline d_staff_pick & $\begin{array}{l}0.3578^{* * *} \\
(0.026)\end{array}$ & $\begin{array}{l}0.3511^{* * *} \\
(0.026)\end{array}$ & $\begin{array}{l}0.3482 * * * \\
(0.026)\end{array}$ & $\begin{array}{l}0.3418^{* * *} \\
(0.026)\end{array}$ & $\begin{array}{r}0.0796 \\
(0.062)\end{array}$ & $\begin{array}{c}0.098 \\
(0.062)\end{array}$ \\
\hline Duration & $\begin{array}{l}-0.0168 * * * \\
(0.001)\end{array}$ & $\begin{array}{l}-0.0166^{* * * *} \\
(0.001)\end{array}$ & $\begin{array}{l}-0.0166^{* * * *} \\
(0.001)\end{array}$ & $\begin{array}{l}-0.0154^{* * * *} \\
(0.001)\end{array}$ & $\begin{array}{l}-0.0148^{* * *} \\
(0.002)\end{array}$ & $\begin{array}{l}-0.0146^{* * *} \\
(0.002)\end{array}$ \\
\hline ln_visual & $\begin{array}{l}0.3190^{* * * *} \\
(0.011)\end{array}$ & $\begin{array}{l}0.3219^{* * *} \\
(0.011)\end{array}$ & $\begin{array}{l}0.3204^{* * * *} \\
(0.011)\end{array}$ & $\begin{array}{l}0.3152^{* * * *} \\
(0.011)\end{array}$ & $\begin{array}{l}0.2578^{* * * *} \\
(0.030)\end{array}$ & $\begin{array}{l}0.2439^{* * * *} \\
(0.030)\end{array}$ \\
\hline Moreinfo & $\begin{array}{l}0.2041^{* * *} \\
(0.015)\end{array}$ & $\begin{array}{l}0.1987^{* * *} \\
(0.015)\end{array}$ & $\begin{array}{l}0.1957 * * * \\
(0.015)\end{array}$ & $\begin{array}{l}0.1933^{* * * *} \\
(0.015)\end{array}$ & $\begin{array}{r}0.0281 \\
(0.044)\end{array}$ & $\begin{array}{l}0.0214 \\
(0.044)\end{array}$ \\
\hline d_US & $\begin{array}{l}.01107 \\
(0.019)\end{array}$ & $\begin{array}{c}.01162 \\
(0.019)\end{array}$ & $\begin{array}{c}0.0094 \\
(0.019)\end{array}$ & $\begin{array}{c}0.0069 \\
(0.019)\end{array}$ & $\begin{array}{l}0.0787 \\
(0.060)\end{array}$ & $\begin{array}{l}0.0648 \\
(0.061)\end{array}$ \\
\hline In_target & $\begin{array}{l}-0.2089 * * * \\
(0.005)\end{array}$ & $\begin{array}{l}-0.2128 * * * \\
(0.005)\end{array}$ & $\begin{array}{l}-0.2112^{* * * *} \\
(0.005)\end{array}$ & $\begin{array}{l}-0.2100^{* * * *} \\
(0.005)\end{array}$ & $\begin{array}{l}-0.2120^{* * * *} \\
(0.015)\end{array}$ & $\begin{array}{l}-0.2075^{* * *} \\
(0.015)\end{array}$ \\
\hline d_ego & $\begin{array}{l}0.0890^{* * * *} \\
(0.017)\end{array}$ & $\begin{array}{l}0.0939^{* * *} \\
(0.017)\end{array}$ & $\begin{array}{l}0.0962 * * * \\
(0.017)\end{array}$ & $\begin{array}{l}0.0903^{* * * *} \\
(0.017)\end{array}$ & $\begin{array}{r}-0.0007 \\
(0.045)\end{array}$ & $\begin{array}{c}-0.0036 \\
(0.045)\end{array}$ \\
\hline d_community & $\begin{array}{c}0.0200 \\
(0.017)\end{array}$ & $\begin{array}{c}0.0249 \\
(0.017)\end{array}$ & $\begin{array}{c}0.0255 \\
(0.017)\end{array}$ & $\begin{array}{c}0.0250 \\
(0.017)\end{array}$ & $\begin{array}{c}-0.0194 \\
(0.048)\end{array}$ & $\begin{array}{c}-0.0170 \\
(0.048)\end{array}$ \\
\hline d_custom & $\begin{array}{l}0.1011^{*} \\
(0.019)\end{array}$ & $\begin{array}{l}0.1022^{* *} \\
(0.019)\end{array}$ & $\begin{array}{l}0.1041^{* *} \\
(0.019)\end{array}$ & $\begin{array}{l}0.1027^{* *} \\
(0.019)\end{array}$ & $\begin{array}{c}0.0408 \\
(0.052)\end{array}$ & $\begin{array}{l}0.0452 \\
(0.052)\end{array}$ \\
\hline Industry dummies & Yes & Yes & Yes & Yes & Yes & Yes \\
\hline Constant & $\begin{array}{l}0.1216 \\
(0.084)\end{array}$ & $\begin{array}{l}0.1713^{* *} \\
(0.084)\end{array}$ & $\begin{array}{l}0.1618^{* *} \\
(0.084)\end{array}$ & $\begin{array}{l}0.1596^{* *} \\
(0.084)\end{array}$ & $\begin{array}{l}0.6339 * * * \\
(0.220)\end{array}$ & $\begin{array}{l}0.8269 * * * \\
(0.220)\end{array}$ \\
\hline Observation & 31389 & 31389 & 31389 & 31389 & 3937 & 3937 \\
\hline McFadden's pseudo $\mathrm{R}^{2}$ & .1918 & .1940 & .1953 & .1930 & .1845 & .1866 \\
\hline Log pseudolikelihood & -15795.132 & -15692.287 & -15628.873 & -16689.617 & -2217.497 & -2212.431 \\
\hline
\end{tabular}

$\dagger p<.1 ; * p<.05 ; * * p<.01 ; * * * p<.001$

difference in offering the community belonging to the entrepreneur rewards in addition to product prepurchase.

In Model II we add the number of previous successful and unsuccessful campaigns posted by project proponents. The explanatory power of the model increases significantly, 
as indicated by the LR test $\left(\chi^{2}(2)=206.28 ; p<.001\right)$. Consistent with literature on serial entrepreneurs' success in subsequent ventures (e.g., Ucbasaran et al., 2003; Westhead et al., 2005), serial crowdfunders enjoy a clear advantage compared over their novice counterparts. The likelihood of a crowdfunding campaign's success increases with a larger number of previous successful campaigns, with the coefficient of number of previous successful campaigns significant $(p<.001)$. With all continuous variables at their mean value and dummy variables at their median value a one-SD increase of number of previous successful campaigns leads to a $20 \%$ increase in the likelihood of a crowdfunding campaign being a success (from $26 \%$ to $32 \%$ ). Interestingly, the greater the number of previous unsuccessful campaigns the more difficult it is for project proponents to reach the target capital during the focal campaign. The coefficient of number of previous unsuccessful campaigns is negative and significant $(p<.001)$. A one-SD increase in the number of previous unsuccessful campaigns leads to an $8 \%$ reduction in the likelihood of a crowdfunding campaign being a success (from $28 \%$ to $26 \%$ ).

In Model III, we add social capital from previous successful campaigns to the specification. The coefficient on this variable is positive and significant $(p<.001)$. A one SD increase in the value of this variable leads to a $20 \%$ increase in the likelihood of success (from $26 \%$ to $31 \%$ ), thus the larger the number of comments provided by backers of previous successful campaigns the higher the chance of success of the subsequent crowdfunding campaigns. Once the number of comments made by backers of previous successful campaigns is included in the model specification, the effect of the number of previous successful campaigns disappears. The coefficient of number of previous successful campaigns in Model III is positive, but not significant. These results show that the positive direct effect of the number of previous successful crowdfunding campaigns is fully mediated by the social capital the entrepreneur had developed through these successful campaigns. To further investigate this mediation effect, we implement Sobel-Goodman tests (Sobel, 1982). Results show that $67 \%$ of the total effect of number of previous successful campaigns is mediated by social capital from previous successful campaigns. These findings provide support for hypothesis 1 .

\section{The Interaction of Social Capital From Previous Successful Campaigns and Social Capital Developed by Backing Others' Projects}

In Model IV, we investigate the interaction between social capital from previous successful campaigns and social capital from backing activity by including in the probit model an interaction term between these two variables. The coefficient of this term is negative and significant $(p<.001)$, suggesting a substitution effect between the two types of internal social capital. However, when interpreting interaction effects in nonlinear models, looking only at the coefficient of the interaction term is not sufficient (Ai \& Norton, 2003). Thus, we plot the relationships in Figure 1.

Figure 1a illustrates the average marginal effect of social capital from previous successful campaigns at different values of social capital from backing activity. The marginal effect is initially positive and significant, but decreases with an increase in the value of social capital from backing activity and is no longer significant when this latter variable reaches the value 2.6, corresponding to the 90th percentile of the variable distribution. Thus, social capital from previous successful campaigns always has a significant effect on the probability of success except for very high values of social capital from backing activity. In Figure 1b, we show the predicted probability of success as a function of social capital from previous successful campaigns, contingent on social capital from backing 
Moderating Effect of Social Capital From Backing Activity on the Association Between the Likelihood of Success of a Crowdfunding Campaign and Social Capital From Previous Successful Campaigns

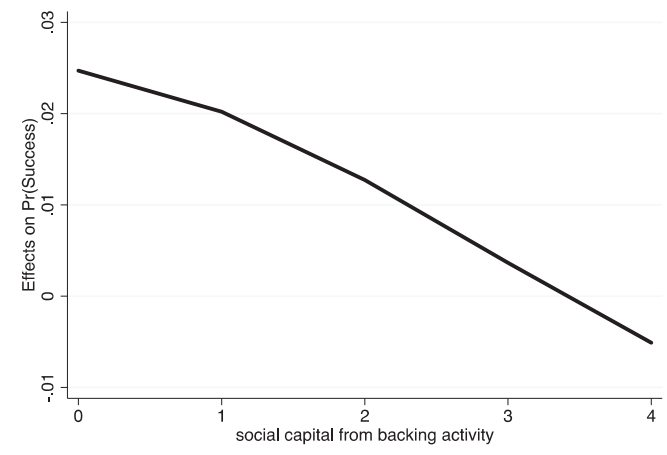

(a) Average marginal effect of social capital from previous successful campaigns

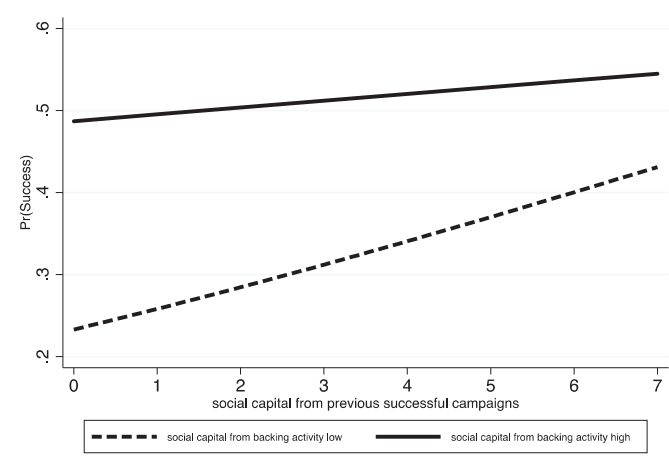

(b) Predicted probability of success

activity taking "low" and "high" values (i.e., values corresponding to the 25th and 75th percentiles of the distribution) and with all remaining variables at their mean (or median) values. When social capital from backing activity takes a "low" value, a one SD increase in the value of social capital from previous successful campaigns results in an $18 \%$ increase in the probability of success (from 23\% to 27\%), while it entails a 5\% increase (from $37 \%$ to $39 \%$ ) when social capital from backing activity takes a "high" value. These results support hypothesis 2 as they show that the social capital that project proponents develop from links with backers of their previous successful campaigns and the social capital they develop by backing (and commenting on) others' projects substitute for each other.

\section{The Role of Time on Social Capital From Previous Successful Projects}

In model V and VI, we investigate how the time elapsed since the last successful crowdfunding campaign moderates the association between the number of comments provided by backers of previous successful campaigns and the likelihood of the focal campaign reaching the target capital. In this case, we restrict our analysis to serial crowdfunders. Thus, the final sample is smaller and consists of 3,937 observations.

As predicted by hypothesis 3 , results show that the positive association between the likelihood of success of a crowdfunding campaign and social capital from previous successful campaigns becomes weaker the longer the time elapsed since the last successful campaign. The coefficient of the interaction term is negative and significant $(p<.001)$. To have a better understanding of the time dependence of this social capital effect, we report in Figure 2a the average marginal effect of social capital from previous successful campaigns when the time elapsed since the previous campaign varies from the minimum to the maximum values. When the time elapsed is low, social capital from previous 
Moderating Effect of Time on the Association Between the Likelihood of Success of a Crowdfunding Campaign and Social Capital From Previous Successful Campaigns

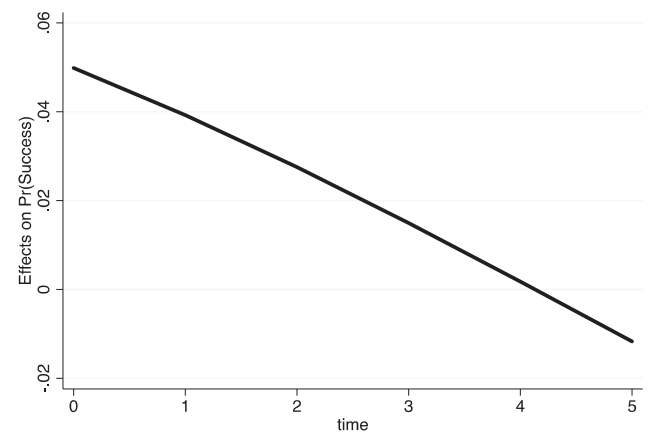

(a) Average marginal effect of social capital from previous successful campaigns

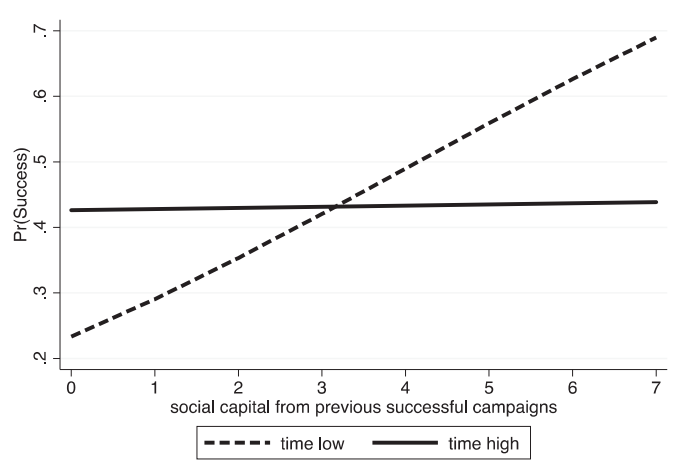

(b) Predictive probability of success

successful campaigns has a positive and significant effect on the likelihood of success. However, when the time since last campaign is sufficiently high (about 1.5 years), the marginal effect of this variable is no longer significant. The weakening of the effect of this variable the longer the time elapsed since the previous successful campaign is even more evident from Figure $2 \mathrm{~b}$. The figure shows the probability of success as a function of social capital from previous successful campaign, contingent on the value of time (values corresponding to the 25th and 75th percentiles of the distribution), with all remaining variables at mean (or median) value. When the time since the last successful campaign is low, a one SD increase in social capital from previous successful campaigns leads to a $13 \%$ increase of the probability of success (from 39\% to 44\%). No significant increase is detected when time takes a high value.

\section{Robustness Checks}

To assess the robustness of our results we performed several additional estimates. First, the analytical approach implemented to compute confidence intervals uses the delta method to approximate the probability distribution for a function of an asymptotically normal statistical estimator. Although this approach is widely used, it may lead to inaccurate estimates and misinterpretation (Zelner, 2009). To address this, we run our estimates using the simulation-based approach recommended by King, Tomz, and Wittenberg (2000), which is particularly convenient as it also implicitly corrects for the bias of the predicted probability estimator formula (King \& Zeng, 2001) and includes the following steps.

We draw one value of the coefficient vector from the multivariate normal distribution with mean $\beta^{*}$, the estimated coefficient vector from the model, and variance matrix $\mathrm{V}$ $\left(\beta^{*}\right)$, the estimated variance-covariance matrix for the coefficient estimates in the model. Then, we set all the covariates to their mean (or median) values and we calculated the 
expected values of the probability of success when the independent variables (number of previous successful campaigns, number of previous unsuccessful campaigns, social capital from previous successful campaigns, social capital from backing activities, and time) vary. We also calculate first-differences, that is, the difference between the expected probability of success at different values of the independent variables. We repeated the algorithm 1,000 times in order to calculate $95 \%$ confidence intervals for the simulated values.

The results obtained by implementing this methodology are fully in line with those presented earlier. The number of unsuccessful campaigns has a negative effect on the likelihood of success, while the number of successful campaigns has a positive effect, although this is mediated by social capital from previous successful campaigns. Moderation effects are also significant. The average marginal effect of social capital from previous successful campaigns is significantly positive both when social capital from backing activity takes "low" and "high" values (i.e., values corresponding to 25 th and 75 th percentiles of the distribution). However, the value of the marginal effect is much higher in the former than in the latter situation. Moreover, as the confidence intervals of the two marginal effects do not overlap, we can conclude that social capital developed by backing others' projects significantly weakens the association between the likelihood of success of a crowdfunding campaign and social capital from previous successful campaigns. Analogous conclusions are inferred about the interaction between time and social capital from previous successful campaigns.

Second, hypotheses on the antecedents of the success of crowdfunding campaigns have been typically tested by mean of probit models with reaching the target capital as an indicator of success. However, scholars have occasionally used different measures of crowdfunding success, namely the amount of pledged capital of the campaign and the number of backers who supported the campaign (e.g., Colombo et al., 2015). We run robust ordinary least squares (OLS) estimations including these latter measures as dependent variables. Results are fully in line with the main models (available from the authors upon request).

A third check relates to the linearity of the effects of the number of successful campaigns and number of unsuccessful campaigns variables. Literature on serial entrepreneurs has detected a detrimental effect on entrepreneurial performance of having run too many firms in the past (Ucbasaran et al., 2009). In line with this view, one may expect a nonlinearity in the relationship between the number of crowdfunding campaigns (either successful or unsuccessful) posted in the past and the probability of success of a focal campaign. To test for the existence of these nonlinear (i.e., inverse U-shaped) effects, we introduced the squared terms for both number of previous successful campaigns and number of previous unsuccessful campaigns to the main model. These terms are not significant, thus hypotheses of nonlinear relationships are rejected in both cases. We performed an analogous test for the variable social capital from successful campaigns and again we did not find any support for nonlinearity in these relationships.

Fourth, we controlled for possible biases due to outliers. Following extant research on the topic (Wainer, 1976), we winsorized continuous variables included in our estimates at the top and bottom $1 \%$. Specifically, we replaced any value above the 99 th percentile by the 99th percentile of the distribution and any value below the 1st percentile with the 1st percentile. Results after winsorization are consistent with those included in the main model. As a further control, we perform a $1 \%, 5 \%$, and $10 \%$ trimming of the data to remove extreme values from the estimates. Results again are consistent.

Fifth, we run the estimations by splitting the sample into project categories. Coefficients of the main variables remain in line with those found in the main model, although 
in some case they are no longer statistically significant (in the categories design, fashion, and food). Finally, we performed an additional check on the variables on rewards. We run our models by substituting the dummy variables indicating the reward category with a continuous variable which counts the number of rewards offered. The coefficient of this variable is not statistically significant and all results are confirmed.

\section{Discussion and Conclusions}

We have investigated whether and why serial crowdfunders, namely entrepreneurs who launched repeated crowdfunding campaigns over time, outperform their novice counterparts. Results from a large sample of reward-based crowdfunding campaigns posted on Kickstarter show that serial crowdfunders' success is mainly related to the "internal" social capital consisting of the links with backers of previous successful campaigns. Indeed, launching several successful crowdfunding campaigns over time gives entrepreneurs the opportunity to interact with backers and is a powerful tool to develop social capital. In turn, this type of social capital has a positive effect on the success likelihood of future crowdfunding campaigns launched by serial crowdfunders. We show that such social capital substitutes for that developed by serial crowdfunders within the platform from backing activity (Colombo et al., 2015). In addition, we document that social capital from previously successful campaigns depreciates over time, having no effect on success likelihood of subsequent crowdfunding campaigns if time elapsed since the last campaign is sufficiently high.

We contribute to extant literature in several respects. First, we add to the emerging crowdfunding literature. Although the number of serial crowdfunders is growing considerably, studies have neglected the existence of such individuals so far. We document that serial crowdfunders are more successful than their novice counterparts, and offer an explanation for this based on the social capital they have developed from links with backers of their previous successful crowdfunding campaigns. Conversely, learning by doing benefits, which are highlighted by the serial entrepreneurship literature, seem to play a relatively less important role for serial crowdfunders. Indeed, our findings indicate that the positive association between the probability of success of a new campaign and the number of prior successful campaigns is fully mediated by the above-mentioned internal social capital. Second, we also contribute to the debate on the role of social capital in crowdfunding by pointing to a new, thus far neglected dimension of the "internal" social capital developed within a crowdfunding platform, based on entrepreneurs' interaction with backers of their previous successful projects. Colombo et al. (2015) have focused attention on the internal social capital developed by backing others' campaigns. We confirm the positive effect of this type of internal social capital, but only for entrepreneurs who lack sufficient social capital from their own previous successful campaigns. Third, the paper contributes to the literature on serial entrepreneurship by providing additional evidence in a new context beyond VC (Zhang, 2011), business angels (Brush et al., 2002), and debt providers (Uzzi, 1999) that serial entrepreneurs accumulate social capital across projects. In so doing, we add to the literature on the role of social capital in serial entrepreneurship particularly in relation to neglected aspects such as antecedents, substitutability, and longevity (Gedajlovic et al., 2013). By showing, in the context of a crowdfunding platform, how social capital is derived from backing others' campaigns and from the backers of serial crowdfunders' own prior campaigns, we provide insights into the different ways that networks can help develop social capital (Jack, 2005) and also how these act as substitutes. Our evidence is aligned to the idea that digital interactions favor the 
rise of weak ties (Ellison et al., 2007). Accordingly, the social capital developed by serial crowdfunders is different from that typically developed by serial entrepreneurs as it is formed by a greater number of weak ties. Building on this argument, and in contrast with existing literature on serial entrepreneurs, we show that this social capital depreciates quite rapidly over time, thus making the advantages of serial entrepreneurship in raising finance for subsequent ventures temporary.

This paper has some limitations that pave the way to further research. First, we measured different forms of "internal" social capital by the number of comments provided and received by serial crowdfunders. This measure extends prior research by considering the "quantity" of interactions between backers and crowdfunders as a proxy of social capital. We also consider the "quality" of these comments and found that the great majority are positive. However, we acknowledge that a more accurate analysis of the content of each comment would provide a more comprehensive understanding of the social capital developed by project proponents (e.g., the specific resources conveyed through each relationship). Second, we limited our analysis to Kickstarter campaigns, and thus do not have information on serial crowdfunders who had launched funding campaigns across different platforms, which may lead to an underestimation of the number of serial crowdfunders. However, we believe that this does not affect our estimations. When a project proponent succeeds in collecting funding on a specific platform, he/she will likely post again a new campaign on the same platform. This is mainly a psychological decision because when individuals achieve success, they typically become overconfident about the effectiveness of their actions (Kisfalvi, 2000) and retain existing strategies (Audia, Locke, \& Smith, 2000). Another motivation for using the same platform relates to backers' behavior. Indeed, backers rarely follow serial crowdfunders when they decide to launch a campaign on a different platform because they face stress and costs related to the creation of a new account and may have attachment to the platform. ${ }^{4}$ Finally, using data from a single platform introduces the need for some caution about the generalizability of our results. Kickstarter is a reward-based platform, so it is not clear whether our findings extend to equity crowdfunding platforms and peer-to-peer lending platforms. Developing a data set including crowdfunding campaigns from multiple platforms would allow future studies to observe if our results on the links between social capital and crowdfunding success are specific to reward-based crowdfunding platforms or are generalizable to any platform type.

Despite these limitations, the paper provides insightful hints for both entrepreneurs and platform managers, broadly confirming that social capital from successful campaigns plays a crucial role in the success of the crowdfunding campaigns. However, this effect vanishes when the time elapsed since the last funding campaign is sufficiently high, hence serial crowdfunders should maintain the social capital developed through previous successful campaigns by posting new funding campaigns over time. Moreover, we highlighted that social capital from earlier campaigns is a substitute for other forms of social capital. Entrepreneurs, who already possess "internal" social capital from previous successful campaigns should avoid backing other projects as a strategy to develop internal social capital. Platform managers interested in building an active community with numerous members should carefully consider our results and design solutions to keep project

4. During 2015, we followed a crowdfunder who launched different projects over time. First, a campaign on an "all or nothing" platform to finance the making of a short movie was successfully launched, helping him realize his project. After a few months, he launched a project to finance the postproduction stage of a new film on a "keep it all" platform attracted by the possibility of cashing in the funding whatever the result of the campaign. This attempt was a complete failure as few previous backers supported him during this new campaign. 
proponents and backers on their platforms, by introducing forums to allow backers and proponents to interact or the implementation of an effective updating system to bring backers frequently to the platform. 5

The paper has an important implication for policymakers too. Studies on serial entrepreneurship have often suggested the need to develop policies that favor serial entrepreneurs in order to maximize the return of public investments. Here, we provide evidence from reward-based crowdfunding that improvements in performance for serial entrepreneurs are only temporary. Policymakers should consider this finding when they decide to develop policies to support entrepreneurship. A clear implication resides in the definition of serial entrepreneurs. Can an individual who launched several projects 10 years ago still be considered a serial entrepreneur? Our results provide initial evidence relating to crowdfunding that suggests the answer may be no. However, other studies should be performed in settings different from crowdfunding in order to clearly answer this question.

Overall, our paper has provided insights into an important emerging aspect of crowdfunding, and as such platforms continue to develop, serial crowdfunders seem likely to become an even more significant part of the entrepreneurial finance market.

\section{REFERENCES}

Adler, P.S. \& Kwon, S.W. (2002). Social capital: Prospects for a new concept. Academy of Management Review, 27(1), 17-40.

Agrawal, A., Catalini, C., \& Goldfarb, A. (2011). The geography of crowdfunding. NBER Working Paper No. W16820. Cambridge, MA: National Bureau of Economic Research. Available at http://Papers.Ssrn. Com/Sol3/Papers.Cfm?Abstract_Id=1770375, accessed 19 November 2015.

Ai, C. \& Norton, E.C. (2003). Interaction terms in logit and probit models. Economics Letters, 80(1), 123-129.

Albrecht, J.W., Edin, P.A., Sundström, M., \& Vroman, S.B. (1999). Career interruptions and subsequent earnings: A reexamination using Swedish data. Journal of Human Resources, 34(2), 294-311.

Antoci, A., Sabatini, F., \& Sodini, M. (2012). See you on Facebook! A framework for analyzing the role of computer-mediated interaction in the evolution of social capital. The Journal of Socio-Economics, $41(5), 541-547$.

Audia, P.G., Locke, E.A., \& Smith, K.G. (2000). The paradox of success: An archival and a laboratory study of strategic persistence following radical environmental change. Academy of Management Journal, 43(5), 837-853.

Baert, C., Meuleman, M., DeBruyne, M., \& Wright, M. (in press). Resource orchestration and portfolio entrepreneurship. Strategic Entrepreneurship Journal.

Baker, W.E., Faulkner, R.R., \& Fisher, G.A. (1998). Hazards of the market: The continuity and dissolution of interorganizational market relationships. American Sociological Review, 63(2), 147-177.

Barney, J. (1991). Firm resources and sustained competitive advantage. Journal of Management, 17(1), 99-120.

Belleflamme, P., Lambert, T., \& Schwienbacher, A. (2014). Crowdfunding: Tapping the right crowd. Journal of Business Venturing, 29(5), 585-609.

5. Recently, similar tools have been introduced on Kickstarter. 
Bengtsson, O. (2013). Relational venture capital financing of serial founders. Journal of Financial Intermediation, 22(3), 308-334.

Bessen, J. (2008). The value of US patents by owner and patent characteristics. Research Policy, 37(5), 932-945.

Blanchard, A.L. \& Markus, M.L. (2004). The experienced sense of a virtual community: Characteristics and processes. ACM Sigmis Database, 35(1), 64-79.

Brettel, M. (2003). Business angels in Germany: A research note. Venture Capital: An International Journal of Entrepreneurial Finance, 5(3), 251-268.

Broschak, J.P. (2004). Managers' mobility and market interface: The effect of managers' career mobility on the dissolution of market ties. Administrative Science Quarterly, 49(4), 608-640.

Brush, C.G., Carter, N.M., Greene, P.G., Hart, M.M., \& Gatewood, E. (2002). The role of social capital and gender in linking financial suppliers and entrepreneurial firms: A framework for future research. Venture Capital: An International Journal of Entrepreneurial Finance, 4(4), 305-323.

Burt, R.S. (2002). Bridge decay. Social Networks, 24(4), 333-363.

Butticè, V. \& Colombo, M.G. (in press). Industry specificity and the effect of internal social capital in reward-based crowdfunding. In S.G Alvarez, E.G. Carayannis, G.B. Dagnino, R. Faraci (Eds.), Entrepreneurial ecosystems and the diffusion of startups. Cheltenham, UK: Edward Elgar.

Butticè, V., Franzoni, C., Rossi-Lamastra, C., \& Rovelli, P. (in press). The road to crowdfunding success: A review of extant literature. In A. Afuah, C. Tucci, \& G. Viscusi (Eds.), Crowdsourcing contexts, Oxford, UK: Oxford University Press.

Chua, C.E.H., Lim, W.K., Soh, C., \& Sia, S.K. (2012). Enacting clan control in complex IT projects: A social capital perspective. MIS Quarterly—Management Information Systems, 36(2), 577-600.

Coleman, J.S. (1988). Social capital in the creation of human capital. American Journal of Sociology, 94, S95-S120.

Colombo, M.G., Franzoni, C., \& Rossi-Lamastra, C. (2015). Internal social capital and the attraction of early contributions in crowdfunding. Entrepreneurship Theory and Practice, 39(1), 75-100.

Cope, J. (2005). Toward a dynamic learning perspective of entrepreneurship. Entrepreneurship Theory and Practice, 29(4), 373-397.

Dahlander, L. \& McFarland, D.A. (2013). Ties that last tie formation and persistence in research collaborations over time. Administrative Science Quarterly, 58(1), 69-110.

Donath, J. \& Boyd, D. (2004). Public displays of connection. BT Technology Journal, 22(4), 71-82.

Eggers, J.P. \& Song, L. (2014). Dealing with failure: Serial entrepreneurs and the costs of changing industries between ventures. Academy of Management Journal, 58(6), 1785-1803.

Ellison, N.B., Steinfield, C., \& Lampe, C. (2007). The benefits of Facebook "friends": Social capital and college students' use of online social network sites. Journal of Computer-Mediated Communication, 12(4), 1143-1168.

Faraj, S. \& Johnson, S.L. (2011). Network exchange patterns in online communities. Organization Science, 22(6), 1464-1480.

Gallager, D. \& Salfen, J. (2015). By the numbers: When creators return to Kickstarter. Available at https://www.kickstarter.com/blog/by-the-numbers-when-creators-return-to-kickstarter.

Gedajlovic, E., Honig, B., Moore, C., Payne, T., \& Wright, M. (2013). Social capital and entrepreneurship: A schema and research agenda. Entrepreneurship Theory and Practice, 37(3), 455-478. 
Gerber, E.M., Hui, J.S., \& Kuo, P.Y. (2012). Crowdfunding: Why people are motivated to post and fund projects on crowdfunding platforms. In Proceedings of the International Workshop on Design, Influence, and Social Technologies: Techniques, Impacts and Ethics.

Gompers, P., Kovner, A., Lerner, J., \& Scharfstein, D. (2010). Performance persistence in entrepreneurship. Journal of Financial Economics, 96(1), 18-32.

Granovetter, M.S. (1973). The strength of weak ties. American Journal of Sociology, 78(6), 1360-1380.

Greer, B.G. (2000). Psychological and support functions of an e-mail mailing list for persons with cerebral palsy. CyberPsychology and Behavior, 3(2), 221-235.

Gulati, R. \& Gargiulo, M. (1999). Where do interorganizational networks come from? American Journal of Sociology, 104(5), 1439-1493.

Hsu, D.H. (2007). Experienced entrepreneurial founders, organizational capital, and venture capital funding. Research Policy, 36(5), 722-741.

Hutto, C.J. \& Gilbert, E. (2014). Vader: A parsimonious rule-based model for sentiment analysis of social media text. ICWSM proceedings. Palo Alto, CA: Association for the Advancement of Artificial Intelligence (AAAI). Available at http://comp.social.gatech.edu/papers/icwsm14.vader.hutto.pdf, accessed 11 January 2017.

Ingram, P. \& Torfason, M.T. (2010). Organizing the in-between: The population dynamics of networkweaving organizations in the global interstate network. Administrative Science Quarterly, 55(4), 577-605.

Jack, S.L. (2005). The role, use and activation of strong and weak network ties: A qualitative analysis. Journal of Management Studies, 42(6), 1233-1259.

Jones, Q., Ravid, G., \& Rafaeli, S. (2004). Information overload and the message dynamics of online interaction spaces: A theoretical model and empirical exploration. Information Systems Research, 15(2), 194-210.

King, G., Tomz, M., \& Wittenberg, J. (2000). Making the most of statistical analyses: Improving interpretation and presentation. American Journal of Political Science, 44(2), 347-361.

King, G. \& Zeng, L. (2001). Logistic regression in rare events data. Political Analysis, 9(2), 137-163.

Kisfalvi, V. (2000). The threat of failure, the perils of success and CEO character: Sources of strategic persistence. Organization Studies, 21(3), 611-639.

Kuppuswamy, V. \& Bayus, B.L. (2015). A review of crowdfunding research and findings. Available at http://papers.ssrn.com/sol3/papers.cfm?abstract_id=2685739, accessed 1 December 2015.

Kwak, H., Moon, S.B., \& Lee, W. (2012). More of a receiver than a giver: Why do people unfollow in Twitter? ICWSM proceedings. Available at https://an.kaist.ac.kr/ haewoon/papers/2012-icwsm-poster.pdf, accessed 22 June 2016.

Lafontaine, F. \& Shaw, K. (2014). Serial entrepreneurship: Learning by doing? NBER Working Paper No. w20312. Cambridge, MA: National Bureau of Economic Research. Available at http://www.nber.org/ papers/w20312, accessed 23 November 2015.

MacMillan, I.C. (1986). To really learn about entrepreneurship, let's study habitual entrepreneurs. Journal of Business Venturing, 1(1), 241-243.

Maurer, I. \& Ebers, M. (2006). Dynamics of social capital and their performance implications: Lessons from biotechnology start-ups. Administrative Science Quarterly, 51(2), 262-292.

Mincer, J. \& Ofek, H. (1982). Interrupted work careers: Depreciation and restoration of human capital. Journal of Human Resources, 17(1), 3-24. 
Mockus, A., Fielding, R.T., \& Herbsleb, J.D. (2002). Two case studies of open source software development: Apache and Mozilla. ACM Transactions on Software Engineering and Methodology (TOSEM), 11(3), 309-346.

Mollick, E. (2013). The dynamics of crowdfunding: Determinants of success and failure. Journal of Business Venturing, 29(1), 1-16.

Mollick, E. \& Nanda, R. (2015). Wisdom or madness. Comparing crowds with expert evaluation in funding the arts. Management Science, doi:10.1287/mnsc.2015.2207

Moran, P. (2005). Structural vs. relational embeddedness: Social capital and managerial performance. Strategic Management Journal, 26(12), 1129-1151.

Nahapiet, J. \& Ghoshal, S. (1998). Social capital, intellectual capital, and the organizational advantage. Academy of Management Review, 23(2), 242-266.

Parker, S.C. (2013). Do serial entrepreneurs run successively better-performing businesses? Journal of Business Venturing, 28(5), 652-666.

Pitschner, S. \& Pitschner-Finn, S. (2014). Non-profit differentials in crowd-based financing: Evidence from 50,000 campaigns. Economics Letters, 123(3), 391-394.

Prashantham, S. \& Dhanaraj, C. (2010). The dynamic influence of social capital on the international growth of new ventures. Journal of Management Studies, 47(6), 967-994.

Preece, J. (1999). Empathic communities: Balancing emotional and factual communication. Interacting with Computers, 12(1), 63-77.

Richter, C. (2015). Crowdcreation as a dimension of crowdsourcing: Conditions for entrepreneurs. International Journal of Entrepreneurial Venturing, 7(4), 324-340.

Seabright, M.A., Levinthal, D.A., \& Fichman, M. (1992). Role of individual attachments in the dissolution of interorganizational relationships. Academy of Management Journal, 35(1), 122-160.

Shaw, E. \& Carter, S. (2007). Social entrepreneurship: Theoretical antecedents and empirical analysis of entrepreneurial processes and outcomes. Journal of Small Business and Enterprise Development, 14(3), $418-434$.

Sobel, M.E. (1982). Asymptotic confidence intervals for indirect effects in structural equation models. Sociological Methodology, 13(1982), 290-312.

Steier, L. \& Greenwood, R. (2000). Entrepreneurship and the evolution of angel financial networks. Organization Studies, 21(1), 163-192.

Trester, J.J. (1998). Venture capital contracting under asymmetric information. Journal of Banking \& Finance, 22(6), 675-699.

Ucbasaran, D., Westhead, P., \& Wright, M. (2009). The extent and nature of opportunity identification by experienced entrepreneurs. Journal of Business Venturing, 24(2), 99-115.

Ucbasaran, D., Wright, M., \& Westhead, P. (2003). A longitudinal study of habitual entrepreneurs: Starters and acquirers. Entrepreneurship \& Regional Development, 15(3), 207-228.

Uzzi, B. (1999). Embeddedness in the making of financial capital: How social relations and networks benefit firms seeking financing. American Sociological Review, 64(4), 481-505.

Vismara, S. (2016). Equity retention and social network theory in equity crowdfunding. Small Business Economics, 46(4), 579-590. 
von Krogh, G., Spaeth, S., \& Lakhani, K.R. (2003). Community, joining, and specialization in open source software innovation: A case study. Research Policy, 32(7), 1217-1241.

Wainer, H. (1976). Estimating coefficients in linear models: It don't make no never mind. Psychological Bulletin, 83(2), 213-217.

Wash, R. (2013). The value of completing crowdfunding projects. ICWSM proceedings. Available at http://citeseerx.ist.psu.edu/viewdoc/download?doi=10.1.1.374.6606\&rep $=$ rep1\&type $=$ pdf, $\quad$ accessed 3 January 2016.

Wasko, M.M. \& Faraj, S. (2000). "It is what one does": Why people participate and help others in electronic communities of practice. The Journal of Strategic Information Systems, 9(2), 155-173.

Wasko, M.M. \& Faraj, S. (2005). Why should I share? Examining social capital and knowledge contribution in electronic networks of practice. MIS Quarterly, 29(1), 35-57.

Wellman, B. \& Gulia, M. (1999). Net surfers don't ride alone: Virtual communities as communities. In B. Wellman (Ed.), Networks in the global village (pp. 331-366). Boulder, CO: Westwiew.

Westhead, P., Ucbasaran, D., \& Wright, M. (2003). Differences between private firms owned by novice, serial and portfolio entrepreneurs: Implications for policy makers and practitioners. Regional Studies, $37(2), 187-200$.

Westhead, P., Ucbasaran, D., \& Wright, M. (2005). Decisions, actions, and performance: Do novice, serial, and portfolio entrepreneurs differ? Journal of Small Business Management, 43(4), 393-417.

Wiklund, J. \& Shepherd, D.A. (2008). Portfolio entrepreneurship: Habitual and novice founders, new entry, and mode of organizing. Entrepreneurship Theory and Practice, 32(4), 701-725.

Wright, M., Robbie, K., \& Ennew, C. (1997). Venture capitalists and serial entrepreneurs. Journal of Business Venturing, 12(3), 227-249.

Zelner, B.A. (2009). Using simulation to interpret results from logit, probit, and other nonlinear models. Strategic Management Journal, 30(12), 1335-1348.

Zhang, J. (2011). The advantage of experienced start-up founders in venture capital acquisition: Evidence from serial entrepreneurs. Small Business Economics, 36(2), 187-208.

Vincenzo Butticè is a research fellow in the Department of Management Economics and Industrial Engineering, Politecnico di Milano, Piazza Leonardo da Vinci, 32, Milan 20133, Italy.

Massimo G. Colombo is full professor in the Department of Management, Economics and Industrial Engineering, Politecnico di Milano, Piazza Leonardo da Vinci, 32, Milan 20133, Italy.

Mike Wright is full professor of entrepreneurship at Imperial College Business School, South Kensington Campus, London SW7 2AZ, United Kingdom, and is visiting professor of entrepreneurship at the University of Ghent, Belgium. 